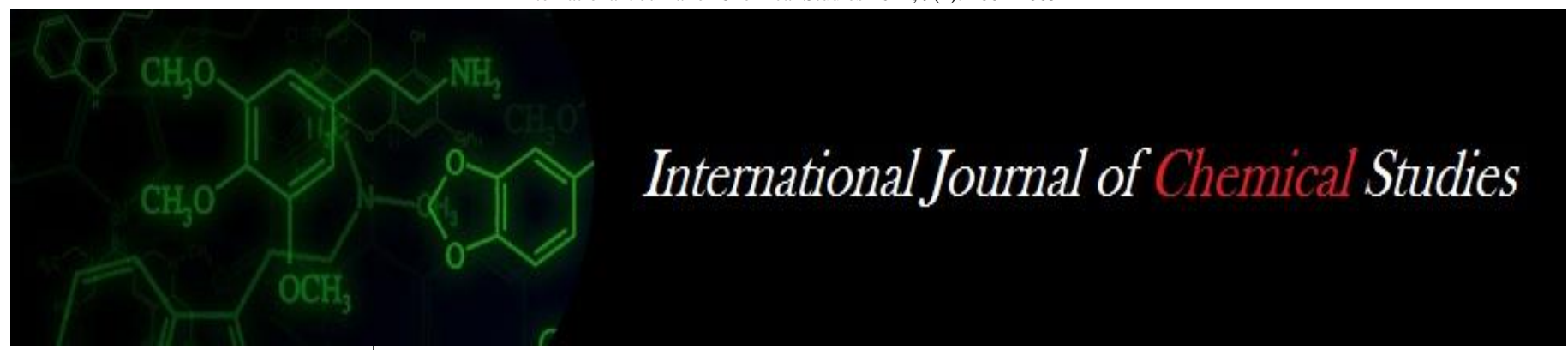

P-ISSN: 2349-8528

E-ISSN: 2321-4902

www.chemijournal.com

IJCS 2021; 9(1): 2662-2665

(C) 2021 IJCS

Received: 15-10-2020

Accepted: 30-12-2020

Babithraj Goud Gaddameedi

Department of Crop Physiology,

PJTSAU, Rajendranagar,

Hyderabad, Telangana, India

Bhagawan Bharali

Department of Crop Physiology, Assam Agricultural University,

Jorhat, Assam, India

Corresponding Author:

Babithraj Goud Gaddameedi

Department of Crop Physiology,

PJTSAU, Rajendranagar,

Hyderabad, Telangana, India

\section{Inter-relationships among economic yield, physiological attributes and nitrogen sulphur status of wheat crop under the influence of sulphur aerosols}

\author{
Babithraj Goud Gaddameedi and Bhagawan Bharali
}

DOI: $\underline{\text { https://doi.org/10.22271/chemi.2021.v9.i1ak.11630 }}$

\begin{abstract}
The younger wheat leaves are fertilized with only nitrogen get started bright green or yellowish green colour. Furthermore, the plants suffering from sulphur deficiency persisted for more time reduces grain yield. Responses of nitrogen, calcium, and potassium along with sulphur. Foliar fed of sulphur aerosols viz., $\left(\mathrm{NH}_{4}\right)_{2} \mathrm{SO}_{4}, \mathrm{CaSO}_{4}$, and $\mathrm{K}_{2} \mathrm{SO}_{4}$ : @ 300 ppm each $(\approx 30 \mathrm{~kg} \mathrm{~N}$ ha-1) along with a control were misted on the plants, on sunny days in the afternoon (after 2-3 P.M.) at three different growth stages i.e. seedling, maximum tillering and spike initiation stages can compensates yield losses. However, the grain yield is increased by application of Sulphur aerosols. Therefore, the total concentration of each of the Saerosols was $900 \mathrm{ppm} \approx 0.9 \%$ on Genotypes (viz., GW-322, GW-366, GW-273, GW-173, JW-336) was accomplished both under Pot (Expt.1) and Field (Expt.2). The correlation studies revealed that Seed yield in GW-366 was positively correlated with no of spike plant ${ }^{-1}$, test weight, spike length, HI, straw yield, NUE, SUE both for field and pot experiments respectively. In case of aerosol treatments, $\left(\mathrm{NH}_{4}\right)_{2} \mathrm{SO}_{4}$ brought positive and significant correlations between seed yield with no of spike plant ${ }^{-1}$, test weight, spike length, HI, straw yield, NUE, SUE. In this study the genotype GW-366 was the most responsive under the influence of foliar fertilization with $\mathrm{S}$-aerosols. Among the $\mathrm{S}$-aerosols, $\left(\mathrm{NH}_{4}\right)_{2} \mathrm{SO}_{4}$ was the most effective in the work. Aim of the study application of Sulphur aerosols foliarly enhances juvenescence of crop plant, retarded blooming, physiological maturity, and yield.
\end{abstract}

Keywords: Correlation studies, economical yield, s-aerosols, wheat

\section{Introduction}

The major premier cereal contributor towards country's food bowl is wheat, and is 2 nd most important cereal crop next to rice. In India wheat occupies total area of 24.23 million hectares with a productivity of 70.26 million tonnes. The food grain requirement of India by the year 2020 is estimated at 109 million tonnes (Shoran et al., 2004) ${ }^{[16]}$. So, there is an urgent need to raise the production of food grain, especially wheat. In traditional wheat growing areas of the country viz., Punjab, Haryana, western Uttar Pradesh etc. there is little scope for increasing the area for this crop. The foliar feeding is a new technique were the nutrient elements were soaking up from the soil through root system and some of these nutrients absorbed through the leaves sprayed on the plant canopy (Bernal et al., 2008).

Application of nutrients or fertilizers utilises by the plant for growth and development. Leaves have thicker cuticles which are coated with a waxy layer makes the penetration of solutes occurs through the cuticle the stomata, leaf hairs and other specialized epidermal cells in and out difficult. Nutrients $1^{\text {st }}$ enter the leaf surface earlier to entering the cytoplasm of a cell. There is on-going argue on penetration pathways plays a key role in nutrient uptake (Fernandez and Eichert, 2009 Oosterhuis, 2009) ${ }^{[5,12]}$.

Retention and penetration of foliar fertilizers in to plant organs epicuticular waxes acts as barrier (Jenks and Ashworth, 1999) ${ }^{[8]}$. However, waxes are hydrophobic and repel water-based sprays. Cuticle acts as permeable to both water and oils, stomata allows $\mathrm{CO}_{2}$ exchange between environment and photosynthetic cells (Marschner, 1995) ${ }^{[11]}$. The stomatal pore is wrapped by two guard cells which regulate the opening/closing of the pore, provides evaporative loss of water, exchange of gases during photosynthesis and for controlling the 
transport of water across the epidermis (Raven and Johnson, 1999) ${ }^{[14]}$.

Foliar-applied nutrients stomatal uptake plays a key role as compared to cuticle penetration. The $1^{\text {st }}$ route available for penetration of solutes into leaves through cuticle partially extends across the stomatal cavity forming cuticle ledges. These cuticle ledges will also interfere with the ability of the stomata to up-take the solutes. However, stomatal penetration appears to be more complex and dependent on more environmental factors than cuticular penetration. Cuticular penetration is a slower process rather than stomatal penetration (Schonherr, 2006; Oosterhuis, 2009; and Dickison, 2000) ${ }^{[15,12,4]}$.

Sulphur plays a key role in chlorophyll formation and building blocks of proteins and effective use of $(\mathrm{N}, \mathrm{P}, \mathrm{K})$ other elements like sulphur there is reduction in protein and yield quality. In general, sulphur content in wheat crop ranges in seed and straw $12 \mathrm{~kg} / \mathrm{ha}$ (5kg/acre). In cereals, grains include yellowing of leaves, delay in maturity due to sulphur deficiency. The ratio of $N$ to $S$ ranges from 10:1 to $7: 1$. Alternative supply source of sulphur is Gypsum (calcium sulphate) amasses in the sub-soil at depths of $30-90 \mathrm{~cm}$ available sulphur in the gypsum may not reaches the plant roots. However, foliar fertilization is rather better than soil application to recover the deficiency of plant. (Mary Ann Nelson 2018) [11]. Sulphur plays diverse structural and functional roles in plants, and exhibit varied responses to sulphur deficiency leading to decreases biomass. In the early 1980 s, studies on foliar application of fertilizers investigated for selected crops, including cereals (Girma et al., 2007; Lunde et al., 2008) ${ }^{[6,10]}$ However, the research was limited to micronutrients in high-value horticultural crops such as potato and tomato. Moreover, increasing productivity with intensive agriculture in these areas is not advisable considering the fact that the adoption of high input approach has led to severe environmental problems as exemplified by the incidence of nitrate pollution of ground water and very quick recession of the water table. (Kaya et al., 2001) ${ }^{[9]}$.

\section{Materials and Methods}

Pot \& Field experiments were conducted during the rabi season (wintertime) for two serial years 2017-18 (Expt.1) \& 2018-19 (Expt. 2). The experimental area is situated at $26^{\circ} 45^{\prime}$ $\mathrm{N}^{\prime}$ latitude and $94^{\circ} 12^{\prime} \mathrm{E}$ ' longitude with an altitude 87 meters above mean sea level.

In case of weather condition, of cold winter (9.4-29.7) with high relative humidity $(55-99 \%)$, low rainfall $(0.15-3.78 \mathrm{~mm})$ and lower bright sunshine (4.16-6.24) hours (Table 1). \& cold winter (10.88-31.11C) with high relative humidity (68-99\%), low rainfall $(0-1.1 \mathrm{~mm})$ and lower bright sunshine (3.6-6.54) hours (Table 2) in two years the crop adept more terminus heat stress at grain filling to mature stage. The relative humidity was reduce in the first and second year.

The experiment was stretched out in a randomised block design (RBD) with two replications. The plot size was $(1.5 \times 1.5 \mathrm{~m})$. Treating the seeds with fungicide Captan @ $2.5 \mathrm{~g}$ $\mathrm{kg}^{-1}$ was mixed thoroughly by agitating them for 5 minutes in a container. Basal application of recommended doses of $\mathrm{N}, \mathrm{P}$, K fertilizers @ 80:46:42 per hectare. Plots are weed free manually and control measures were taken to prevent the pest insect attack.

The foliage of plants were misted with S-aerosols @ 300 ppm $\left(\approx 30 \mathrm{~kg} \mathrm{~S} \mathrm{ha}{ }^{-1}\right) @$ three stages of the crop (viz., at seedling stage, maximum tillering stage and spike initiation stages). Each of the S-aerosol (1000ml for a single stage) was applied in 3 splits on cloud free and clear sunny days in the afternoon when air temperature was low. The cumulative volume of one aerosol solution was $0.9 \%(\approx 300 \mathrm{ppm} \times 3=900 \mathrm{ppm})$ only. While spraying the aerosol solutions, its drifting was checked from one plant to another using hard board as partition between two plots. A digital $\mathrm{pH}$ meter with standard $\mathrm{pH}$ (4\&7) was used to measure the $\mathrm{pH}$ of the S-aerosols which were found as distilled water (7.00); $\left(\mathrm{NH}_{4}\right)_{2} \mathrm{SO}_{4}$ (5.34); $\mathrm{CaSO}_{4}$ (5.49); $\mathrm{K}_{2} \mathrm{SO}_{4}$ (5.66).

Five wheat varieties (viz., GW-322, GW-366, GW-273, GW173, JW-336) were gathered from the eastern wheat-growing zones of India (viz., Uttar Pradesh, Madhya pradesh).

Table 1: Meteorological data during the crop season pot experiment

\begin{tabular}{|c|c|c|c|c|c|c|}
\hline \multirow{2}{*}{ Months } & \multicolumn{2}{|c|}{ Temperature $\left({ }^{\circ} \mathbf{C}\right)$} & \multirow{2}{*}{$\begin{array}{l}\text { Mean Relative Humidity } \\
\text { morning hrs. }(\%)\end{array}$} & \multirow{2}{*}{$\begin{array}{c}\text { Mean Relative Humidity } \\
\text { evening (hours) }(\%)\end{array}$} & \multirow{2}{*}{$\begin{array}{l}\text { Monthly total } \\
\text { Rainfall (mm) }\end{array}$} & \multirow{2}{*}{$\begin{array}{l}\text { Monthly total Bright } \\
\text { sunshine (hours) }\end{array}$} \\
\hline & Max. & Min. & & & & \\
\hline December & 26.3 & 11.9 & 99 & 62 & 0.15 & 6.24 \\
\hline January & 25.2 & 9.4 & 98 & 57 & 2.1 & 5.77 \\
\hline February & 26.8 & 13.0 & 95 & 55 & 1.38 & 4.99 \\
\hline March & 29.78 & 15.74 & 97 & 58 & 3.78 & 4.16 \\
\hline Total & & & & & 7.41 & 21.16 \\
\hline
\end{tabular}

Table 2: Meteorological data during the crop season field experiment

\begin{tabular}{|c|c|c|c|c|c|c|}
\hline \multirow{2}{*}{ Months } & \multicolumn{2}{|c|}{ Temperature $\left({ }^{\circ} \mathbf{C}\right)$} & \multirow{2}{*}{$\begin{array}{l}\text { Mean Relative Humidity } \\
\text { morning hrs. }(\%)\end{array}$} & \multirow{2}{*}{$\begin{array}{l}\text { Mean Relative Humidity } \\
\text { evening (hours) }(\%)\end{array}$} & \multirow{2}{*}{$\begin{array}{l}\text { Monthly total } \\
\text { Rainfall (mm) }\end{array}$} & \multirow{2}{*}{$\begin{array}{l}\text { Monthly total Bright } \\
\text { sunshine (hours) }\end{array}$} \\
\hline & Max. & Min. & & & & \\
\hline December & 25.8 & 10.88 & 99 & 69 & 0.0 & 6.54 \\
\hline January & 25.2 & 12.34 & 98 & 69 & 2.7 & 5.57 \\
\hline February & 26.89 & 15.56 & 91 & 71 & 4.6 & 4.59 \\
\hline March & 28.38 & 16.35 & 95 & 75 & 1.1 & 3.6 \\
\hline Total & & & & & 8.4 & 20.3 \\
\hline
\end{tabular}

\section{Collection of Soil samples and analysis}

Sampling spots were cleaned with a spade. khurpi were used for soil collection. First, a ' $\mathrm{V}$ ' shaped cut was made up to the plough layer $(0-15 \mathrm{~cm})$ and then a uniform $1.5 \mathrm{~cm}$ thick slice was taken out. The collected soil samples were completely mixed on a clean piece of polythene sheet. Soil sampling was done at random or in a zigzag manner. About 500g of composite sample was maintained in a clean polythene bag. The process of sample size-quartering method was applied to make four parts by drawing a positive sign. Discard the soil from opposite corners, and repeat the same for its analysis. 
Table 3: Physico-Biochemical properties of soil in the experimental plots

\begin{tabular}{|c|c|c|c|}
\hline Sl. No. & Particulars & Mean values & Reference values (Baruah and Borthakur, 1997) \\
\hline 1. & & & $\begin{array}{c}\mathrm{pH} 4.5=\text { Extremely acid } \\
\mathrm{pH} 5.0=\text { Very strong acid } \\
\mathrm{pH} 5.5=\text { Strong acid } \\
\mathrm{pH} 6.0=\text { Medium acid } \\
\mathrm{pH} 7.0=\text { Neutral }\end{array}$ \\
\hline 2. & Available N & 4.9 & $\begin{array}{c}<272(\mathrm{~kg} / \mathrm{ha}) \\
272-544(\mathrm{~kg} / \mathrm{ha}) \\
>544(\mathrm{~kg} / \mathrm{ha})\end{array}$ \\
\hline 3. & Available P & $285.10 \mathrm{~kg} \mathrm{ha}^{-1}$ & $\begin{array}{c}<22.5(\mathrm{~kg} / \mathrm{ha}) \\
22.5-56.0(\mathrm{~kg} / \mathrm{ha}) \\
>56.0(\mathrm{~kg} / \mathrm{ha})\end{array}$ \\
\hline 4. & Available K & $24.45 \mathrm{~kg} \mathrm{ha}^{-1}$ & $<136(\mathrm{~kg} / \mathrm{ha})$ \\
& & $158.32 \mathrm{~kg} \mathrm{ha}^{-1}$ & $136-337.5(\mathrm{~kg} / \mathrm{ha})$ \\
& & & $>337.5(\mathrm{~kg} / \mathrm{ha})$ \\
\hline 5 & Available S & $17.94 \mathrm{kgha}^{-1}$ & $<20.5(\mathrm{~kg} / \mathrm{ha})$ \\
& & & $20.5-55.0(\mathrm{~kg} / \mathrm{ha})$ \\
\end{tabular}

\section{Determination of $\mathrm{pH}$ of aerosol or soil}

$\mathrm{pH}$ of the aerosols or the soil samples was determined using a digital $\mathrm{pH}$ meter. For standardization, the electrode of the $\mathrm{pH}$ meter were put into two buffer solutions at $(\mathrm{pH} 4.0,7.0)$ one after another, there-by adjusted the $\mathrm{pH}$ values to the standards before measuring the $\mathrm{pH}$ of the aerosols or soil solution. Care was taken (by rinsing in distilled water after each measurement) to eliminate any contamination adhered on the electrode, or the sample solution (Jackson, 1973) ${ }^{[7]}$.

\section{Determination of available nitrogen, phosphorous,} potassium, sulphur

Available nitrogen, phosphorous, potassium, sulphur (kg ha-1) in soils was determined by Kjeldahl Method, Bray's I method, $\left(\mathrm{NH}_{4} \mathrm{OAc}\right)$ method, Turbidimetric method (Black 1965; Jackson, 1973) ${ }^{[7]}$.

\section{Statistical analysis}

Data for each plant parameter was analysed by Fisher's method of analysis of variance. Significance or non- significance of variance due to the treatment effects was resolute by calculating the respective ' $F$ ' values. For analysis MS-excel sheets were used for manual setting of the calculation formulae. (Panse and Sukhatme, 1978) ${ }^{[13]}$.

$\operatorname{S.Ed}( \pm)=\frac{\sqrt{2 \times \text { error mean square }}}{\text { Pooled number of replication }}$

$\mathrm{CD}=\mathrm{S} . \mathrm{Ed} . \times \mathrm{t}_{0.05}$

\section{Correlation studies}

Simple Correlation was computed using Pearson's equation to reveal the magnitude and directions of relationships between seed yield and among economic yield, physiological attributes and nitrogen status of wheat crop under the influence of sulphur aerosols. The correlation coefficient were determined for the selected parameters linked to yield for the varieties and aerosols separately. The probability levels at (0.05) and (0.01) were used for testing the significance of relationships.

Table 4: Correlation studies among the sulphur, nitrogen and yield status of wheat affected by foliar sulphur aerosols among the varieties in field and pot experiments

\begin{tabular}{|}
\begin{tabular}{|c|c|c|c|c|c|c|c|c|}
\hline Varieties & No. of Seed Per Spikes & Spike Weight & Test Weight & Spike Length & HI & Straw Yield & NUE & SUE \\
\hline GW-322 & 0.205351 & 0.205351 & -0.48531 & $0.601318^{*}$ & -0.60845 & 0.416023 & 0.104399 & $0.99438^{* *}$ \\
\hline GW-366 & $0.910953^{* *}$ & -0.60566 & $0.981009^{* *}$ & 0.454461 & $0.837773^{*}$ & $0.749033^{*}$ & $0.599618^{*}$ & $0.917887^{* *}$ \\
\hline GW-273 & 0.189403 & -0.92227 & 0.280589 & 0.451663 & 0.002519 & -0.73835 & 0.498208 & $0.713901^{*}$ \\
\hline GW-173 & $0.64441^{*}$ & $0.871794^{* *}$ & -0.0829 & 0.307612 & 0.167932 & 0.42807 & 0.425795 & $0.914772^{* *}$ \\
\hline JW-336 & 0.335384 & -0.99662 & -0.38266 & $0.680745^{*}$ & -0.75523 & -0.99828 & $0.555289^{*}$ & $0.536904^{*}$ \\
\hline Varieties & No. of Seed Per Spikes & Spike Weight & Test Weight & Spike Length & HI & Straw Yield & NUE & SUE \\
\hline GW-322 & $0.981896^{* *}$ & $0.710445^{*}$ & $0.991273^{* *}$ & $0.991273^{* *}$ & $0.985469^{* *}$ & $0.768515^{*}$ & -0.29193 & $0.581801^{*}$ \\
\hline GW-366 & $0.751802^{*}$ & $0.716874^{*}$ & $0.543193^{*}$ & $0.570327^{*}$ & 0.06745 & 0.417806 & $0.579847^{*}$ & $0.622082^{*}$ \\
\hline GW-273 & $0.770007^{*}$ & 0.310876 & $0.910627^{* *}$ & 0.379129 & $0.988524^{* *}$ & -0.99615 & 0.229228 & $0.91212^{* *}$ \\
\hline GW-173 & -0.56464 & $0.75999^{*}$ & $0.992282^{* *}$ & -0.48175 & -0.30086 & $0.734879^{*}$ & -0.4575 & $0.780595^{*}$ \\
\hline JW-336 & $0.815822^{*}$ & $0.988663^{* *}$ & $0.995532^{* *}$ & -0.46443 & $0.680803^{*}$ & 0.540143 & $0.786078^{*}$ & $0.906807^{* *}$ \\
\hline
\end{tabular}
\end{tabular}

Table 5: Correlation studies among the sulphur, nitrogen and yield status of wheat affected by foliar sulphur aerosols among the treatments in field and pot experiments

\begin{tabular}{l}
\begin{tabular}{|c|c|c|c|c|c|c|c|c|}
\hline Treatments & No. of Seed Per Spikes & Spike Weight & Test Weight & Spike Length & HI & Straw Yield & NUE & SUE \\
\hline $\mathrm{CaSO}_{4}$ & 0.052381 & 0.088812 & 0.119672 & 0.40676 & -0.75594 & 0.398247 & $0.76375^{*}$ & $0.886961^{*}$ \\
\hline$\left(\mathrm{NH}_{4}\right)_{2} \mathrm{SO}_{4}$ & $0.615511^{*}$ & -0.34741 & 0.415136 & $0.923586^{* *}$ & -0.35582 & $0.646023^{*}$ & $0.963914^{* *}$ & 0.400163 \\
\hline $\mathrm{K}_{2} \mathrm{SO}_{4}$ & $0.918255^{* *}$ & $0.751014^{*}$ & $0.920917^{* *}$ & $0.989174^{* *}$ & -0.21452 & $0.85239^{*}$ & 0.501957 & 0.456117 \\
\hline $\mathrm{Control}$ & $0.76421^{*}$ & $0.709227^{*}$ & 0.532405 & $0.604583^{*}$ & 0.089572 & $0.996829^{* *}$ & 0.160688 & $0.682783^{*}$ \\
\hline Treatments & No. of Seed Per Spikes & Spike Weight & Test Weight & Spike Length & HI & Straw Yield & NUE & SUE \\
\hline $\mathrm{CaSO}_{4}$ & $0.916106^{* *}$ & $0.980587^{* *}$ & $0.92538^{* *}$ & 0.31303 & $0.93218^{* *}$ & $0.895103^{*}$ & 0.02661 & $0.957266^{* *}$ \\
\hline$\left(\mathrm{NH}_{4}\right)_{2} \mathrm{SO}_{4}$ & $0.998458^{* *}$ & $0.981536^{* *}$ & $0.999398^{* *}$ & $0.76779^{*}$ & $0.927551^{* *}$ & 0.214538 & 0.343577 & 0.303431 \\
\hline
\end{tabular} \\
\hline
\end{tabular}




\begin{tabular}{|c|c|c|c|c|c|c|c|c|}
\hline $\mathrm{K}_{2} \mathrm{SO}_{4}$ & 0.405127 & 0.314729 & 0.361054 & 0.546088 & $0.908035^{* *}$ & $0.903888 * *$ & 0.520589 & $0.699605^{*}$ \\
\hline Control & $0.942553 * *$ & $0.886298 *$ & $0.995729 * *$ & $0.773431 *$ & $0.999731 * *$ & $0.975992 * *$ & 0.511831 & 0.081179 \\
\hline
\end{tabular}

\section{Discussion}

$\mathrm{S}$ deficiency required to avoid yield losses and to assure efficient use of $\mathrm{S}$ fertilisers. The N:S ratio was better rather than the total $S$ concentration of the vegetative tissue of wheat. speedy accumulation of amides in roots in response to the interruption of $\mathrm{S}$ supply Glutathione also responds markedly to S supply and has been found to act as a signal to govern sulphate uptake and transport. Analysis of these compounds may provide an early evidence of $\mathrm{S}$ deficiency in plants.

The correlation studies revealed that Seed yield in GW-366 was positively correlated with no of spike plant ${ }^{-1}$ $(0.910953 * *, \quad 0.751802 *)$, test weight $(0.981009 * *$, $0.543193 *)$, spike length $(0.454461 *, 0.570327 *)$, HI $\left(0.83773^{*}, 0.06745\right)$, straw yield $\left(0.749033^{*}, 0.983933^{* *}\right)$, NUE $\left(0.599618 *, 0.5798479^{*}\right)$, SUE $\quad(0.917887 * *$, $0.622082 *$ ) both for field and pot experiments respectively. In case of aerosol treatments, $\left(\mathrm{NH}_{4}\right)_{2} \mathrm{SO}_{4}$ brought positive and significant correlations between seed yield with no of spike plant $^{-1}\left(0.998458 * *, 0.615511^{*}\right)$, test weight $(0.999398 * *$, $0.415136)$, spike length $\left(0.76779,0.923586^{* *}\right)$, straw yield $(0.214538,0.646023 *)$, NUE $(0.343577,0.963914 * *)$, SUE (0.303431, 0.400163) both for field and pot experiments respectively. Thus, among the aerosols, $\left(\mathrm{NH}_{4}\right)_{2} \mathrm{SO}_{4}$ (@30 $\mathrm{kgha}^{-1}$ ) could be the applied as foliar spray to explore the potential economic yield of the selected wheat varieties. Because, $\left(\mathrm{NH}_{4}\right)_{2} \mathrm{SO}_{4}$ not only supported $\mathrm{S}$ and $\mathrm{N}$-nutrition, but also maintained the CMS with higher retention of intercellular and exchangeable ions in wheat.

\section{Conclusion}

Thus, it concluded that and revealed there is a correlation between seed yield with spike plant ${ }^{-1}$, test weight, spike length, straw yield. Because of foliar application of Sulphur aerosols at different stages (maximum tillering stage and spike initiation stage) effect the crop growth in field and pot experiment significantly. $\left(\mathrm{NH}_{4}\right)_{2} \mathrm{SO}_{4}$ brought positive and significant correlations comparing with other treatments $\left(\mathrm{CaSO}_{4}, \mathrm{~K}_{2} \mathrm{SO}_{4}\right)$. Nitrogen \& Sulphur application will improve the vegetative growth and plant to attain a greater biomass, thereby increasing yield of the crop.

\section{References}

1. Baruah TC, Barthakur HP. A textbook of Soil Analysis. Vikash Publishing, PVT Ltd. New Delhi 1997.

2. Bernal M, Cases R, Picorel R, Yruela I. Foliar and root $\mathrm{Cu}$ supply affect differently $\mathrm{Fe}$ and $\mathrm{Zn}$ - uptake and photosynthetic activity in soybean plants. Environ. Exp. Botany 2007;60:145-150.

3. Black CA. Method of soil analysis. Part II American society of agronomy Madison, Wisconsin, USA 1965.

4. Dickison WC. Integrative Plant Anatomy (Academic Press: USA) 2000.

5. Fernandez V, Eichert T. Uptake of hydrophilic solutes through plant leaves: current state of knowledge and perspectives of foliar fertilization. Crit. Rev. Pl. Sc 2009;28:36-68.

6. Girma K, Martin KL, Freeman KW, Mosali J, Teal RK, Raun WR et al. Determination of optimum rate and growth for foliar applied phosphorus in corn. Comm. Soil Sci. Plant Anal 2007;38:1137-1154.
7. Jackson ML. Soil chemical analysis. Asia Publishing House, New Delhi 1973.

8. Jenks MA, Ashworth EN. Plant epicuticular waxes: Function, production and genetics. Hort. Re 1999;23:129.

9. Kaya C, Kirnak H, Higgs D. Enhancement of growth and normal growth parameters by foliar application of potassium and $\mathrm{P}$ in tomato cultivars grown at high $\mathrm{NaCl}$ salinity. J Plant Nutr 2001;24:353-367.

10. Lunde C, Zygaldo A, Simonsen HT, Nielsen PL, Blennow A, Haldrup A. Sulfur starvation in rice: The effect on photosynthesis, carbohydrate metabolism, and oxidative stress protective pathways. Physiologia Plantarum 2008;134:508-521.

11. Marschner H. Mineral Nutrition of Higher Plants. (Academic Press Ltd.) Mary Ann Nelson 2018. Wheat nutrition and fertilizer requirement's 1995.

12. Oosterhuis D. Foliar fertilization: mechanisms and magnitude of nutrient uptake. In Proceedings of the fluid forum. 15-17 February, 2009, Phoenix, Arizona 1995.

13. Panse VG, Sukhatme PV. Statistical methods for Agricultural workers, ICAR, New Delhi 1978.

14. Raven PH, Johnson GB. Evolutionary history of plants. In Biology (WCB/McGraw-Hill: Boston, MA) 1999, 645-664.

15. Schonherr J. Characterization of aqueous pores in plant cuticles and permeation of ionic solutes. J Exp. Bot 2006;57:2471-2491.

16. Shoran J, Sharma RK, Tripathi SC. New varieties and production. The Hindu Survey of Indian Agric 2004, 3035. 